\title{
The IWMA and the Commune
}

\section{A Reassessment}

\author{
Quentin Deluermoz \\ Translated by Angèle David-Guillou
}

\begin{abstract}
The formidable insurrection, which the bravery of our army has just defeated, has held the entire world in such anxieties and terrified it by such horrifying infamies that I feel it is necessary to rise above the horror it inspires in order to untangle the causes which made it possible [...] Alongside parodist Jacobins [...] one must place the leaders of a now regrettably infamous society called "The International", whose action was perhaps even more powerful than that of its accomplices, because it relied on numbers, discipline and cosmopolitanism. ${ }^{1}$
\end{abstract}

This excerpt, from a circular sent by the French Foreign Affairs minister, Jules Favre, to Western embassies, may illustrate the dual questioning this contribution raises.

First of all, it revives the problem put forward to politicians, exiles and historians from 1871 onward: what was the real significance of the International Working Men's Association (IWMA) in the Commune events?

Secondly, it also suggests that this interrogation is not new and has been previously researched: the circular, and the extract here considered, are systematically referred to by most of the studies on the Commune and on the IWMA. Consequently, we may ask ourselves whether more findings still lie ahead.

Whatever the answer might be, we will first take a look at what has been done, the conclusions, more or less definite, which have been drawn, and the questions that remain unanswered. Thenceforth, we will be able to examine, modestly, other potential research leads.

1 Circular issued by Jules Favre, Foreign Affairs minister, 6 June 1871. 


\section{Case Closed?}

The corpus produced on the subject is appropriately considerable, the fruit of an international endeavour, structured around research meetings, centres and programmes. Overall, it is located within the scope of social and economic history, of a labour history focused on organisational structures and the labour movement, of Marxist or Marxian questionings, and of a great attention to facts, attested by numerous, meticulous publications of archival documents.

For this paper, we have drawn upon some of this vast continent's landmark analyses, starting from the first writings of Samuel Bernstein in 1941 up to the large endeavours of the 196os and 1970s-1964 colloquium, 1971 colloquium, publications of the Mouvement Social, the work of Alexander Lehning, the Jalons pour une histoire de la commune de Paris and the extensive bibliographical venture led by the Maitron - to which can also be added the more recent general studies on either the IWMA or the Commune. With surveys, primary sources and general studies so readily available, ${ }^{2}$ we can consider what historians' responses to J. Favre's horrified opinions have been.

With regard to the links between the organisation and the Parisian events, between the IWMA and the Commune, things appear to be more or less well established. Revived after the 1867-1868 strikes, the French IWMA found itself very weakened in $\mathbf{1 8 7 0}$, in particularly following imperial repression. At

2 Serge Bernstein, "The First International on the Eve of the Paris Commune”, Science and Society, 5/1 (1941), pp. 24-42; id. "The Paris Commune”, Science and Society, 5/2 (1941), pp. 117-147; Jacques Rougerie, Maximilien Rubel (eds.), "La Première Internationale”, Mouvement social, 51, January-March 1966 ; “Colloque universitaire pour la commémoration du centenaire de la Commune de 1871, Paris, 21-23 mai 1971”, Mouvement social, 79, April-June 1972; La Première Internationale, l'institution, l'implantation, le rayonnement (Paris, 1968); Jacques Rougerie, Tristan Haan, Georges Haupt, Miklos Molnar (eds.), "Jalons pour une Histoire de la Commune de Paris", International Review of Social History, 17/1-2 (1972); Julian P.W. Archer; The First International in France, 1864-1872, its origins, theories and impact (Lanham [etc.], 1997); Bernard H. Moss, The Origins of the French Labor Movement. The Socialism of Skilled Workers, 1830-1914 (Berkeley [etc.], 1976). Jean Maitron, Dictionnaire biographique du mouvement ouvrier français, 1964-1997 (online: biosoc.univ-parisı.fr); Arthur Lehning, De Buonarroti à Bakounine (Paris, 1977); Matthieu Léonard, L'Emancipation des travailleurs. Une histoire de la Première Internationale (Paris, 2011); Michel Cordillot, Aux origines du socialisme moderne. La première internationale, la Commune de Paris, l'exil (Paris, 2010); Michel Cordillot, "L'Association internationale des travailleurs des travailleurs du mouvement ouvrier moderne (1865-1871)" in Michel Pigenet, Danielle Tartakowsky (eds.), Histoire des mouvements sociaux en France (Paris, 2012); Jacques Rougerie, La Commune de 1871 (Paris, 2009); Robert Tombs, Paris, Bivouac des révolutions (Paris, 2014); Laure Godineau, La Commune de Paris par ceux qui l'ont vécu (Paris, 2010). 
that time membership in France reached several dozens of thousands, spread across different centres - Paris, Rouen, Lyon, etc.-, to which had to be added non-affiliated sympathisers. ${ }^{3}$ Nevertheless this dynamism appeared to be slowing down around the outbreak of the July 1870 war, although, it seems, the phenomenon mustn't be overestimated concerning grass-root organisation in Paris. In London, the General Council, at first cautious about the military events, opposed the war of "conquest", especially after the proclamation of the Republic on 4 September and Prussia's declaration of intent to annex Alsace-Lorraine. The General Council welcomed the advent of the Republic 9 September address - whilst affirming its non-engagement until peace had been reached. Meanwhile, in Prussia, the Brunswick committee opposed the war -5 September declaration -, before being suppressed by the Prussian authorities.

The Parisian sections of the IWMA were very active during the siege, alongside other organisations to which they were more or less closely linked: vigilance committees and the central committee of all twenty Parisian arrondissements, garde nationale and even some district councils such as that of the seventeenth ${ }^{\mathrm{h}}$, etc. In an important article, ${ }^{4}$ Jacques Rougerie showed that the journey from November 1870 to May 1871 consisted of complex ebbs and flows. If Blanquists dominated certain sections from November onward, by contrast the other sections remained mainly republican - in the sense that they favoured a democratic and social Republic - or associationist.

It is also well known that IWMA's members played almost no role in the events of $18 \mathrm{March}$, which was a popular and spontaneous movement. These men, who for the large part belonged to the qualified trades of the capital shoes, bronze, Paris articles and employees -, were nevertheless present at the structural level of the Paris insurrections: thirty-two out of ninety-two at the Commune Council - intendancy for Varlin, postal service for Theisz, education for Vaillant. They could also be found amongst the officers of the garde nationale. ${ }^{5}$ Their role within the Commission du travail and towards the reorganisation of work relations particularly stood out: the creation of local trades councils, organisation of women's work, enabling of the development of labour associations, etc. But there, as elsewhere, time was short for this

3 Jacques Rougerie, "Les sections parisiennes de l'AIT" and Jean Maitron, "Les effectifs de l'AIT", in La Première Internationale, l'institution, l'implantation, le rayonnement.

4 Jacques Rougerie, "L'AIT et le mouvement ouvrier à Paris pendant les événements de 18701871", Jalons pour une Histoire de la Commune de Paris, pp. 3-102.

5 Léonard, L'Émancipation des travailleurs. During the trials some would say that "it is enough to say that we are in the International to be directly recruited amongst the officers". 
Commune, which only "babbled a system". ${ }^{6}$ Mostly, it appears quite problematic to describe this role and associate it to only one affiliation: did these men only act as "Internationalists" during the Commune? Was this their sole identity within insurrectional Paris, and if so what conclusions can be drawn? The question has notably been raised with regard to the famous schism of 1 May between a "minority" and a "majority", following the proposal to create a Committee of Public Safety. For a long time it was assumed that Internationalists mainly belonged to the "minority", opposing the "Jacobins" and "Blanquists" of the "majority". In fact, a detailed analysis of the votes suggests a more nuanced view: if the majority of the "minority" was made of Internationalists, the majority of Internationalists voted on the side of the "majority".

The General Council was closely following the events, but with certain circumspection. The choice of holding elections on 26 March elections, and most of all the Parisian patriotic feeling - a rerun of 1789-1794-, surprised many, in particularly Karl Marx. Even Auguste Serrailler, boot-maker and member of the French International, who acted as an intermediary between London and Paris, noted this patriotic fever, that affected even local internationalists. Support from the General Council thus remained constant but distant, all the more that the address aimed at proclaiming this support was not immediately known, due to Marx's illness. The activity of the General Council intensified after the events, especially as it had to respond to the attacks from the British, American and French press.

At the French national level, what were the relations between the IWMA and the provincial communalist movements? Here again, the role of the International has been explored, but perhaps less thoroughly than in the case of Paris. Maurice Moissonnier, who researched the Commune in Lyon at great length, wrote a national history of those movements, illustrated with a comprehensive map, in the Jalons. This overview was later refined by more localised surveys and by comparative studies by the like of Louis Greensberg and Michael Hanagan. ${ }^{8}$

6 Jacques Rougerie J, La Commune de 1871 (Paris, 2009).

7 Rougerie, "L'AIT et le mouvement ouvrier à Paris pendant les événements de 1870-1871", p. 68.

8 Maurice Moissonnier, "La Province et la Commune", Jalons pour une Histoire de la Commune de Paris, pp. 151-182; Maurice Moissonnier, La Première internationale et la Commune à Lyon, 1865-1871 (Paris, 1972); Michael P. Hanagan, Nascent Proletarians: Class Formation in Post-Revolutionary France (Oxford, 1989); Archer; The First International in France ; Louis M. Greenberg, Sisters of Liberty. Marseille, Lyon, Paris and the Reaction to a Centralized State, 1868-1871 (Harvard, 1971). 
The role of Internationalists and their affiliates in Marseilles and Lyon, Rouen and Saint-Etienne has also been identified. In Bordeaux, in a less favourable context, the members of the section of the IWMA were wavering between joining and rejecting radical republicans, especially at the time of the elections. But their ideas and a certain attraction for the Commune permeated some battalions of the garde nationale, as revealed in April..$^{9}$ Some of the surveys also suggest that a section created in Martinique may have played a role in the September 1870 insurrections in the south; this point must be further investigated..$^{10}$ On the whole, the variety of situations is noted and the conclusion is often the same: members of the local sections of the IWMA seldom played a decisive role in the initiation of the insurrections, whether it was in September 1870 or in April 1871, and the demarcations with the other active groups - radical republicans, liberal republicans, qualified and unqualified workers, national guard, etc. - were permeable and uncertain. Nevertheless, Internationalists could, as they did for strikes, share their organisational and political expertise as well as their concern for the lot of the working-class. The importance of their role varied depending on the militants, their past political trajectories and local balances of power.

What we would today refer to as the transnational dimension of the subject is also well documented. Monographs on individuals - Fränkel, Lavrov, Cluseret, etc.-, but also on countries and specific geographic zones are available. By their reinterpreting of various political and national contexts - Great Britain, Belgium, Germany, Austria, Hungary, Ireland, Switzerland, Italy, Spain, Poland, Romania, Georgia, the United States and Latin America - these studies expose the ways in which the local sections of the IWMA echoed and relayed the republican experience of September 1870 and later the communalist endeavour of March 1871. ${ }^{11}$

Thus in Spain, according to Carlos S. Serrano, the Commune was applauded by both the republicans, who saw it as the illustration of the Federal Republic, and by the Internationalists, closer to Bakunin and Proudhon, who instead

Jacques Girault, Bordeaux et la Commune, 1870-1871: mouvement ouvrier et idéologie républicaine au moment de la Commune de Paris (Périgueux, 2009.).

10 Marcelo Segall, "En Amérique latine, développement du mouvement ouvrier et proscription", Jalons, pp. $325^{-369}$. The section is mentioned at the 1865 London conference, then in the report of the 1866 Lausanne conference. It does not appear in any work written after the insurrection; see for instance Gilbert Pago, L'Insurrection de Martinique, 1870-1871 (Paris, 2011); and Silyane Larcher, L'Autre citoyen. L'universalisme républicain et les esclaves émancipés de la Caraïbe française (XVIIIe-XIXe) (Paris, 2014.).

See La Première Internationale, l'institution, l'implantation, le rayonnement ; and Jalons. 
highlighted its social dimension. ${ }^{12}$ Internationalists also organised marches to demonstrate their support - in Budapest in May 1871, as well as in London and Geneva. ${ }^{13}$ Some even defended the Commune in front of their legislative chambers: August Bebel, who was both an Internationalist and an elected member of the Reichstag - in the specific backdrop of the creation of the German social democracy ${ }^{14}$ - stood in defence of the Parisians, in Germany, on 25 May, in a speech that has remained famous.

In addition, many more studies exist on the subject of exiles. ${ }^{15}$ Individuals, their organisations, activities, surveillance and integration in local society are known, in the case of Switzerland, England, Belgium and the United States. ${ }^{16}$ The is true of Latin America, too, although in less detail: Mégy, Chardon, Fribourg, as well several local activists in Marseilles, Lyon, Le Creusot and Bordeaux, travelled there following the revolutionary reflux, and contributed to the creations of sections - in Argentina on 28 January 1872, but also Chile, Mexico, etc.

Finally, the effects of the Commune events on the IWMA have equally been scrutinised. These include the demonising of the organisation, having suddenly become the centre of all attention, its mistaken for Bakunin's Alliance programme, and perceived association with the secret societies of the first nineteenth century - the Charbonnerie, Marianne, etc. Another focus has been the governmental offensives arising from the Favre circular - whether they were direct, as in France, Spain and Portugal, or resulted in surveillances and pressure in Germany and Austria-Hungary. The measures put in place with

12 Carlos S. Serrano, "L'Espagne, la Commune et l'Internationale", Jalons, pp. 222-239.

13 Marc Vuillemier, in La Première Internationale, l'institution, l'implantation, le rayonnement; Jiri Koralka in La Première Internationale, l'institution, l'implantation, le rayonnement ; for the London meetings, see the minutes of the General Council.

14 Ernst Engelberg, in La Première Internationale, l'institution, l'implantation, le rayonnement. See also Roger Morgan, The German Social democracy and the first international 1864-1872 (Cambridge, 1965).

15 Sylvie Aprile, Le Siècle des exilés : bannis et proscrits de 1789 à la Commune (Paris, 2010); Regarding Commune exile, see the PhD dissertation of Laure Godineau, Retour d'exil. Les anciens communards au début de la Troisième République (PhD, Paris I University, 2000). See also Thomas C. Jones, Robert Tombs, "The French left in exile: Quarante-huitards and Communards in London, 1848-80", in Debra Kelly and Martyn Cornick, The French in London. Liberty, Equality, Opportunity (Londres, 2013).

16 Vuillemier in La Première Internationale, l'institution, l'implantation, le rayonnement; Jan Dhondt, in La Première Internationale, l'institution, l'implantation, le rayonnement; Michel Cordillot, Révolutionnaires du Nouveau monde: une brève histoire du mouvement socialiste francophone aux États-Unis, 1885-1922 (Montréal, 2009). 
regard to refugees reflected latent Euro-American divisions of opinion: Spain agreed to facilitate extraditions whereas Belgium, Switzerland, the United Kingdom and the United States refused, not without facing opposition, to review their asylum laws, often under the conjugated effect of liberal traditions, pressure groups and movements of opinions for the most appalled by the "horrors" of the Commune, but still rejecting any reappraisal.

Post-Commune local contexts are also documented: trade-union walkouts in London; debates between Mazzini and Garibaldi in Italy; developments in Spain after the Valence conference (marked by the influence of Bakunin, although less absolute than originally thought); repercussions in Latin America, etc. On the whole, the studies conclude on a collapse of the IWMA in France and Great Britain, and of a surge in Italy, Spain, Belgium and the United States. ${ }^{17}$

Following a similar line of thought, the question of the role of the Commune in the collapse of the IWMA in 1872 has of course been examined. The incendiaries and execution of hostages - the Versailles massacre having been almost completely removed from media discourse - impacted on the legitimacy of local struggles, bringing about debates between republicans and socialists, the reversal of a liberal opinion that was more benevolent before, and a redefinition of internationalist socialism. Further "structural" interpretations were put forward to explain this failure. According to Marcel Van der Linden, the collapse of the IWMA was not so much due to the Commune or to the internal Marx/Bakunin dispute - which, most studies agree, crystallised a much more complex field of debate - but was in fact the consequence of structural modifications: the Franco-Prussian war dynamic; nationalisation and growing government control, as exemplified by the German and Italian cases, and the economic crisis. In this regard, the IWMA, as well as the Commune, was a specific moment in the history of labour, within general external conditions. ${ }^{18}$

Therefore, a large body of research can be found, from which two aspects emerge. First of all, the gap between, on one side, the small number of members and results, and, on the other, the strong symbolic weight of the IWMA - according to Jan Dhondt, for instance, the "myth of the IWMA" would have encouraged a growing sense of class consciousness. Secondly, the idea that in this untoward collision between the IWMA and the Commune resides the origins of modern socialism - more complex than first anticipated. Thus

17 See the studies by Molnar and Dhondt, in La Première Internationale, l'institution, l'implantation, le rayonnement.

18 Marcel Van der Linden, "The rise and fall of the First International: an Interpretation", in Frits Van Holthoon, Marcel Van der Linden, (eds.) Internationalism in the Labour Movement, 1830-1940 (Leiden, 1988), pp. 323-335. 
Jules Favre's question had already been answered forty years ago. With few marginal exceptions, most of this answer derives from what appears to be a conscientious collective historical endeavour. And if these conclusions are marked by questionings typical of the periods that produced them, they gave rise to contradictions and debates and are certainly worthy of mention; at a time when historical objects are "transnationalised", doing so allows us to highlight the fact that an important body of work is indeed available. Supplementing more recent works on movements of rebellion and large-scale opposition, many dealing with the French revolution of 1848 and the anarchist movement after $1880,{ }^{19}$ these studies conveniently point out that the $1848-1880$ period is as important a field of research, and that existing data can still be analysed and discussed. So my second point is: do further questions remain to be asked? Can other approaches, sometimes even already suggested by the studies themselves, be considered?

\section{The 186os' "banners of revolt"}

Until more detailed analyses are produced, four lines of investigation can be suggested. The first would concern the organisational dimension of the IWMA, notably on the Parisian front. As noted before, much is known about the affairs of the IWMA during the Commune, but there are gaps in the sources; thus, it is still difficult to apprehend intermittent and lesser-known protagonists or their trajectories. Nonetheless, it is possible to reassess the interactions between the sections of the IWMA and other political and paramilitary organisations - garde nationale, vigilance committee, clubs, and district authorities - in order toexplore their role in the events' dynamic. The question is particularly pertinent as to the modus operandi of mobilisation. This aspect has been considered in the case of other revolutions, such as Mark Traugott's famous "organisational hypothesis", apropos the "garde mobile" of $1848,{ }^{20}$ and Haim Burstin's anthropological analysis of the ebbs and flows of "revolutionary energy" during the French revolution..$^{21}$ The fluctuations in sections' membership, during the

19 Peter Linebaugh, Marcus Rediker, The Many-Headed Hydra: Sailors, Slaves, Commoners, and the Hidden History of the Revolutionary Atlantic (Boston, 200o); Benedict Anderson, Under Three Flags: Anarchism and the Anti-Colonial. Imagination (London [etc.], 2005).

20 Mark Traugott, Armies of the Poor:Determinants of Working-Class Participation in the Parisian Insurrection of June 1848, (Princeton, 1985).

21 Haim Burstin, Révolutionnaires. Une anthropologie politique de la révolution française (Paris, 2013). 
1869-1871 period, could be considered in this same perspective. We would then be able to understand how these organisations reacted to the political crisis, but also how they were used, and the way in which their role were constantly redefined. The best way to do this would be to research the micro-history of an arrondissement or a neighbourhood sufficiently documented in the period 1870-1871. Such studies are lacking, a few exceptions notwithstanding. ${ }^{22}$ A case study, even if too circumscribed, can nevertheless make it possible to envisage the level of observation required. On 11 May 1871, a group of people was sent by Théophile Ferré, deputy public prosecutor of the Commune, to take control of the Champs-Elysées police station, in the 8th arrondissement. In this very hostile "reactionary" district, ${ }^{23}$ the new officers carried out several searches in the houses of imperial dignitaries - including that of the Duke of Rivoli, chamberlain of the Empire, at 8 rue Jean Goujon - and sent their belongings to La Monnaie. The fact that Démophile Coussat, commissaire de police (chief superintendent), shoemaker and militant, was also an Internationalist, was probably not a coincidence: this affiliation, the revolutionary path and discipline, as well as the faith which, at least superficially, these would seem to imply, were likely to have enabled the pursuit of actions of this kind on hostile ground, far from local reasoning and based on the inter-knowledge of working class neighbourhoods logics of the North East. ${ }^{24}$ Thus, membership of the International could have an impact on intermediary structures in the insurrectional Paris. This helps better comprehend the relations of power, suspended and constantly recomposed, that beset the Commune, sometimes on the smallest of scales.

Perceived from the point of view of these complex processes, the growing divergences with the General Council, itself involved in a trajectory of its own, appear even more obvious: experiences and expectations dissolved, whilst a link remained, at least on the London side. These distortions call for a reappraisal of the structures of the IWMA: no longer a fixed and controlled framework, but a driving belt between several initiatives, constantly in the process of being defined and crystallised. Thereupon, it would be interesting to look more closely at the modalities of contact between the Parisian sections, and

Iain Chadwick, "Revolutionary Neighbourhoods and Networks during the Paris Commune of 1871" (PhD., University of Oxford, 2011) ; Robert Tombs, "Prudent Rebels; the 2nd arrondissement during the Paris Commune of 1871", French History, 5:4 (1991), pp. 393-413 ; For 1848, a good illustration of this approach can be found in Laurent Clavier, "Quartier' et expériences politiques dans les faubourgs du nord-est parisien en 1848", Revue d'histoire du XIxe siècle, 33 (2006), pp. 121-142.

23 Archives de la Préfecture de Police, рв 511. Report by Billot, former superintendent.

24 Service Historique de l'Armée de Terre, 8J, 3 e conseil, dossier 976 "Coussat"; and Archives Nationales (AN), BB 24, $85^{2}$. 
between the sections and the General Council in London. The minutes of the General Council reveal that information was transmitted orally, via individuals who managed to travel, such as Serraillier who made the return journey, by mail, but also, and mostly, by the press, which undoubtedly represents an essential aspect of the period. This meant that London members had to be extremely cautious at all times. On 14 February, the General Council received news of Serrailler through a report published in the Pall Mall Gazette. And on 25 April, Marx described the chaotic journey of a letter written by Lafargue, which he had only just received: ${ }^{25}$ it was sent outside of the fortifications, slowed down by the disruptions affecting the railway system, controlled by Prussian and French authorities... In addition to vertical networks, horizontal networks between sections also seemed to be in place: in 1870, the German section in Paris provided the IWMA section in Budapest with a German edition to inform them of the trial of the Association in France. Did these networks survive during the Siege and then the Commune? Were there many of them? ${ }^{26}$

A second group of interrogations would relate to what might be called "intellectual history". The aforementioned research of the 1960 s and 1970s clearly suggest looking into that direction. One of the recurrent approaches consisted in opposing the "socialist" views of the IWMA with regard to the "romantic revolutionaries" of 1848 and the "liberal republicans", thus suggesting strict typologies and sometimes even value judgements. With regard to the Commune, as it seems impossible to establish a clear ideological line, it is often presented as an ideological mishmash, exemplified by the famous 19 April poster and by the multiplicity of opinions amongst its elected representatives.

But these perspectives have been criticised, from the great colloquia onwards, in favour of more complex gradations. At the level of the IWMA, ideas were manifold and the vote, by a majority, of the general orientations during congresses - collectivist after 1866, etc. - at no time implied a definitive "conceptual clarification", neither in London, nor at the local level. In addition, it would be incorrect to associate the ideas and beliefs of Parisian IWMA militants as well as of other people involved in the revolutionary movement, under the Commune, to Proudhonist ideas only. Jacques Rougerie suggests other intellectual links: ${ }^{27}$ the ideas of Charles Renouvier, J. Fauvety and C. Pecqueux, whose propagations and interpretations remained to be defined, in view of the lack of research on the Second Empire labour milieu. Other worlds of

\footnotetext{
25 Minutes of the General Council of the First International.

26 Tibo Erenyi, in La Première Internationale, l'institution, l'implantation, le rayonnement.

27 Rougerie, "L'AIT et le mouvement ouvrier à Paris pendant les événements de 1870-1871", Jalons ; Rougerie, La Commune de 1871.
} 
references must be considered. Most of the actors involved in the International or the Commune were, and this is unique, qualified workers, with specific work ethics and regulation cultures that would need to be identified..$^{28}$ The same would have to be done in respect to the vocabularies of moral economy and of the "bon droit", both particularly mobilised. ${ }^{29}$ Then, probably, gestures, in addition to discourses, should be put under scrutiny: the use of searches, sometimes led by Internationalists, was also a political act, fully part of the concrete republic embodied by the Commune and justified in the clubs by the expression "diminish the castle and elevate the worker's home". ${ }^{30}$ Finally, the events resulted in resurgences and discontinuities: ${ }^{31}$ this is how must be understood the strong presence of a democratic and social republic project in 1848 and of the French revolution of 1789-1794 - even if these references could led to several interpretations. Thus, we must ask whether a language, an interpretation and even a voice specific to Internationalists were in effect, at least amongst the eldest ones, and what type of cross-influences were created?

It could be useful to focus more specifically on encounters. The Work Commission, for instance, was placed under the control of Internationalists who acted in favour of a unionisation of the means of production. But they were confronted, in their enterprise, by numerous petitions of workers - the society of tallow chandlers, the society of saddlers ${ }^{32}$ - who used a language close to that of 1848: technical demands mixed with general values; will to associate; patriotic language, etc. The elected representatives, who belonged to a notso-dissimilar background, had to respond to the pleas of those trades, and encourage them. The exchanges must have been complex, on such a malleable terrain, and studying them would contribute to a better understanding, in situ, of the multiple expectations and definitions then at stake.

Similarly, it would perhaps be interesting to closely follow the utilisation and significance of certain expressions, such as the language surrounding the idea of "class" and of "workers' emancipation". The latter had been in use since

28 Following previous research on the world of urban trades, Geoffrey Crossick (ed.), The Artisan and the European Town, 1500-1900 (Aldershot, 1997); Yves Lequin, Les Ouvriers de la région lyonnaise: 1848-1914 (PUL, 1977); Jean-Louis Robert, Danielle Tartakowsky (eds.), Paris le peuple: XVIII -Xxe siècle (Paris, 1999).

Quentin Deluermoz, "La Commune et le vol, ou les périmètres mouvants de la propriété au XIXe siècle", in Frederic Chauvaud, Arnaud-Dominique Houte, Au voleur! (Paris, 2014).

30 "Abaisser le château et élever la chaumière".

31 Michèle Riot-Sarcey, "Temps et histoire en débat", Revue d'histoire du XIXe siècle (2002), pp. $7^{-13}$.

32 See Jacques Rougerie, Paris Libre, 1870-1871 (Paris, Seuil, 2004). 
the 1840 s, and was palpably present in $1848^{33}$ and, later on, in 1871 . But were there inflexions in these usages, notably after the great wave of strikes in the 1860 s and the presence, even if only symbolic, of the IWMA? This was what the 1848 revolutionary Joseph Benoit suggested when he complained, in 1869, about the multiplication of strikes and the discourse on class struggle related to the International. Referring to the organisation he observed that: "it was only later that the International Society became involved in politics and social reform by exaggerating those issues [...]. It pushed workers in the direction of strikes and its action was preponderant". 34

Surprisingly, numerous studies of this kind were published about the $1830 \mathrm{~s}$ and 1840s, in France (on utopian socialism), and most of all in Great Britain (around Chartism and its language ${ }^{35}$ ). The Commune and its discursive profusion could well be scrutinised through the lens of the type of questioning then raised - concentrating less on theoretical publications and more on the web of texts available, and refusing to take for granted the existence of a link between social status and language. With this approach in mind, it would also be of interest to reconsider the impact of the events in the radicalising of positions, both in Paris and London. The General Council, it is known, was driven by this situation and asserted itself against it too. Undoubtedly, beyond a more typical history of ideas, there is enough here to revisit the thoughts and beliefs of the different protagonists involved, whether workers or not, revolutionaries or not, and interrogate from this angle the ideas, thus put back "in context", related to the IWMA. ${ }^{36}$

A third investigative path could rethink the transnational perspective. As we have seen, much research has been done on the echoes of the Commune via the IWMA, on the roles of exiles in the dissemination of the sections after 1871 , and several national histories of the sections of the IWMA have been published. Nevertheless, as far as we are aware, there is no general study on the

33 Rémi Gossez, Les Ouvriers de Paris, 1: L'Organisation, 1848-1851 (Paris, 1968); Jacques Rougerie, "Le Mouvement associatif populaire comme facteur d'acculturation politique à Paris de la Révolution aux années 1840 : Continuité, Discontinuités”, Annales Historiques de La Révolution Française, 297 (1994), pp. 493-516; Maurizio Gribaudi, Paris, ville ouvrière. Une histoire occultée (1789-1848) (Paris, 2014).

34 Joseph Benoît, Les Confessions d'un prolétaire (Lyon, 1968), p. 269.

35 Michèle Riot-Sarcey, Le Réel de l'utopie : essai sur le politique au XIXe siècle (Paris, 1998). See also the research by ANR Utopie 19 ; Gareth Stedman Jones, "Rethinking chartism", in Languages of Class (Cambridge, 1984), pp. 90-178; Malcolm Chase, Chartism: a new History (Manchester, 2005).

$3^{6}$ In reference to the suggestions made by the School of Cambridge. 
repercussions of the Commune as a whole, even if several relevant points can be made.

The first point relates to the trajectories of Internationalists, notably of the few who also played a role during the Commune. Many of the latter were already akin to the international struggles of the post-1848 years. The most famous of them, Cluseret, was on the side of the "gardes nationales de l'ordre" in 1848. He settled in Algeria, took part in the Italian wars, the American Civil War and the Fenian movement in Ireland in 1866, and later reappeared in the Lyon and Marseilles Communes, before becoming a general under the Paris Commune. It was also the case of Dombrowski, a Polish national and a protagonist in the Polish insurrection of 1863 , who arrived in France in 1865 , and of many other, lesser-known activists. This said, all French Internationalists, including some of the most influential ones like Eugène Varlin, did not share the same experience. Similarly, all Republican volunteers were not Internationals, far from it; in fact, many moved away from the social question to remain anchored in a system based on military heroism, typical of the first nineteenth century. But it is obvious that there were also direct connexions between these movements; they would need to be looked at again.

It is possible, secondly, to push forward the study of the impact of the Commune; if the sections of the IWMA acted as relays, they were not the only ones. In Spain, as previously noted, support for the Commune often came from workers and republicans, at least for a time. In Chile, only liberal Francophiles, such as Eduardo de la Barra, opposed conservative landowners. In Romania, the proclamation of a Republic, and later of the Commune, shook the general population to such an extent that it worried Prussia. It had a particular resonance amongst liberals and the supporters of a national liberation opposed to Carol I, before his socialist inkling softened their fieriness. ${ }^{37}$ The trajectories were multiple. The questions of temporal depth and of the adaptation to fluid national configurations have been highlighted by Alberto Garcia Balaña in this volume, in the case of Spain, and, for the United States, by Michel Cordillot who followed the trails of French migrant refugees between both countries in the nineteenth century. ${ }^{38}$ The Commune, Sphinx-like, was a "crossroad",39 subjected, from the month of March, to the most varied appreciations and appropriations on a global scale. Thus we must confront a misty landscape of multiple, heterogeneous situations, which are connected, more or less, to one

\footnotetext{
37 Georges Haupt, "La Roumanie", Jalons, pp. 477-489.

38 Cordillot, Révolutionnaires du nouveau monde.

39 See Robert Tomb's conclusion at the Narbonne colloquium, 2011 (organised by Marc César, Laure Godineau, Xavier Verdejo).
} 
another. This perspective does not necessarily imply an undermining of the particularities of the Paris Commune - the kinds of "bottom-to-top" politics that were implemented, or the strength of the myth of the French capital - on the contrary, it sheds a new light on them and makes a place for reassessment.

The global histories of the nineteenth century are, for the most part, embarrassed by the Commune. Considered too unlike the post-1848 movements and the revolutions of the twentieth century, it is sometimes described as a hapax legomenon. ${ }^{40}$ In fact, as we have seen, it appears to be an event of international dimension moored to a larger movement of republican and social struggles affecting the years 1840-1880. The IWMA acted as a material and discursive articulation, original but not unique, between these experiences. We can observe, by the way, that little has been said about the colonies and the imperial sphere - either regarding the addresses emanating from the IWMA or the tangible consequences of the Commune. Yet an insurrection, opposing former slaves, from before 1848 , against white landowners, shook Martinique in September 1870; and during the essentially republican troubles in Algiers, the Commune seemed to have served as a reference, before the perception of its social dimension led, here again, to a dissociation. ${ }^{41}$ Was the IWMA interested in these events? It did not appear to be present in those territories, even if the question persists, as we have seen, in the case of Martinique. Does this suggest a difference in attitudes or is it just that this dimension has not been scrutinised as closely? In any case, more needs to be done in this field, too.

Finally, the concept of "temporality" must be tackled. Indeed, one problem arises today from the wave of studies flagged earlier in this article: their rather teleological nature. Of course, it is not the case for all the authors, and the analyses are often more subtle. But this general trend exists and it is palpable, for instance, in the remarks on the "lack of maturity" of the workers or in the investigation of the "modern" aspects of the labour movement. It is true that everything then seemed to go in that direction: the image of the Commune, between dusk and dawn; the idea of a First International which precedes the Second; the historiographical questionings of the 1960s and 1970s; and even the theoretical tools, as those of Charles Tilly on the repertoires of action.

40 Jürgen Osterhammel, Die Verwandlung der Welt: eine Geschichte des 19. Jahrhunderts (München, 2010); Christopher Bayly, The Birth of the Modern World, 1780-1914: Global Connections and. Comparisons (Maiden [etc.], 2004) ; Fabrice Bensimon, "L'Internationale Des Travailleurs", Romantisme, 163 (2014), pp. 53-62.

41 On the subject of Algiers, see Archives Nationales d'Outre Mer Aix, F8o 1682. Vuillermoz, Algiers's Mayor, signed "Commune d'Alger" ("Algiers Commune") in January. This communard dimension was suggested in a letter from Algiers's Prefect to the French Home Secretary, 8 April 1871; the impact of the Commune in Constantine was also noted by the Prefect of Constantine in a letter dated 18 April 1871. A more detailed research is ongoing. 
In an interesting text on nineteenth-century Marseilles dockworkers, which includes the Marseilles Commune, W. Sewell Jr. denotes the predominance of this teleological narrative in labour history, and looks for ways of avoiding it. ${ }^{42}$ For that purpose he considers three types of "temporality": routines (that which repeats in time), trends (long-term tendencies) and events (which are irruptions and potential displacements of structure). Of course, these three temporalities are always intertwined; they are observational tools that should enable the development of less orientated temporal analyses.

In this perspective, the binomial Commune-IWMA may represent a genuine opportunity. There is a trend, the development of the IWMA and its sections, and an event, the Commune, thus a means, precisely, to displace the focus. Consequently, the period could be approached not from the point of view of its origin but of its specificity, with the temporal discontinuities it involves.

Therefore, it would be necessary to re-evaluate the Commune "event" itself, following the works started by J. Rougerie and R. Tombs. Studies show that even if this perception increasingly prevailed in 1869 , it was indeed the Commune that in reality elevated the IWMA to the status of an international issue after April-May 1871. The Parisian episode, with its traumatising images of incendiaries, the massacre of hostages and their echo in the press, was the source of the stereotypical idea of a monstrous Commune-IWMA coupling, which later became the object of so many investigations. Such post-event requalifications are known. ${ }^{43}$ Besides, the Commune and its repercussions triggered, as we have seen, a series of recompositions within the field of social and political conflicts, with infinite local variations. But such readjustments also affected governmental politics; we have cited the reluctance to change the rights of asylum in certain countries. Further aspects should also be looked at: police cooperation, as it became stronger after 1848 , around The Great Exhibition in London; ${ }^{44}$ the question of the usage of passports, at the centre of numerous diplomatic discussions; and the wielding of liberal international law, which witnessed profound displacements in the 1860 os. $^{45}$ The Commune, and its association with the IWMA, is only a small piece of a much larger reconfiguration,

42 William H. Sewell, Logics of History: Social Theory and Social Transformation (Chicago, 2005).

43 Roger Chartier, Les Origines culturelles de la Révolution française (Paris, 1990).

44 For Germany, for instance, see Matthieu Deflem, "International Policing in nineteenthcentury Europe: The Police Union of German States, 1851-1866”, International Criminal Justice Review, 6 (1996), pp. 36-57.

45 Andreas Fahrmeir, Citizenship: The Rise and Fall of a Modern Concept (New Haven, Conn., 2007); Davide Rodogno, Against Massacre: Humanitarian Interventions in the Ottoman Empire, 1815-1914 the Emergence of a European Concept and International Practice (Princeton, 2012); Rachel Chrastil, The Siege of Strasbourg (Harvard, 2014). 
which brought forth latent tensions. As a current study of diplomatic archives suggests, the influence of its image is perhaps not yet perfectly known. ${ }^{46}$ In Brazil, for instance, both chambers voted a "solemn declaration" to express the "horrifying feeling inspired by the anarchy that destroyed most of the French capital" and to welcome "the victory of civilisation and Christianity". Thus, the global nature of the Commune should be investigated: "global", in that it was part of a vast transnational and transcontinental force field; "event", in that it created a series of displacements, a "change of structure" - to use W. Sewell's vocabulary -, but one which mainly affected state institutions. It modified, without being its only impetus, previous socio-political configurations. ${ }^{47}$

Those questionings logically call for the previous period to be reconsidered, notably from 1848 to 1871 . Historians have somewhat neglected its European and imperial dimensions, with the assertion of political measures oscillating between liberalisation and authoritarianism, leaning towards nationalisation and government control, with heterogeneous mutations of the forms of industrialisation, the rise of the press, commerce and the intensification of the French and British colonial endeavours. In these conditions, the perpetuation of the democratic struggles after 1848 , and the assertion of social conflicts, took on a different tonality, partially crystallised in 1870 and 1871 . Hence the "banners of revolts" did not wait until the 1880 s to be exhibited, and the singularity of the IWMA experience is made extremely apparent. Here stretches an entire field of investigation that must be pursued for this fascinating period. The aim would be to more acutely restore the ways of seeing, the possibilities of action, the modalities of the conflict, and the adjusted hopes of each actor. This would benefit existing interrogations of the relations between the Commune and the IWMA, and enrich our understanding of the period directly following.

Those last suggestions may illustrate the underlining driving force of the second part of our argument: perhaps have we only applied to the object here at stake the forms of historical investigations renewed since the 1980 s namely the rejection and assignations of predefined categories (highbrow/

46 This study is based on French, English and American archives. See here: Centre d'Archives Diplomatiques, Nantes, $573 \mathrm{PO} / \mathrm{A} / 47$, Rio de Janeiro, départ, 1870-1871. There is in fact a double-faceted confusion here: between the Alliance and the IWMA, and between the IWMA and the Commune. The social imaginary of conspiracy, in the first nineteenth century, apparent in the Favre circular, could be further studied in its various forms: both disconnected from facts and extremely efficient ; see Jean-Noel Tardy, L'Âge des ombres : Complots, conspirations et sociétés secrètes au XIXe siècle (Paris, 2015).

47 Naturally, these recompositions had an influence, after, on the signification and the symbolic impact of the Commune for the labor movement. 
lowbrow, working-class/bourgeoisie), the articulation between practices and representations, the study of actors and their actions, the issue of scales, connected analysis, etc.? So the relation between the IwMA and the Commune has become multiform, suggesting, from this initial tension, new interrogations about each phenomenon, as close as possible to the level of the protagonists. This is continuing the displacements researched in the course of the 1970s. The referential background is not only historiographical: what we call today the end of ideologies, the mutations of the rule of historicity, the disintegration of social movements in favour of more heterogeneous and reticular struggles, the assertion of the globalisation and of "emerging countries" influence this way of seeing. The great investigations of the 1950 and 1960 can then, in return, help minimise the anachronism implied by our contemporary outlook, reminding us of the importance of the economic dimension, the function, even if limited, of organisations and their militants, the role of German speaking countries and of central Europe, and therefore the meanings of the effort that went into this search for unity, beyond the diversity of situations. Many a survey are still to be led in order to understand the multiple and complex connections which existed between the IWMA and the Commune - and the world it revealed starting with the documents already unearthed and others which must be tracked down. Whether this collective endeavour will be as intense as the one we have described, is less certain. 


\section{LIBERTY, EQUALITY,SOLIDARITY, FRATERNITY.}

\section{Anniversary of the 18th of March, 1871} (COMMUNALIST REVOLUTION OF PARIS.)

The International Federal (French) Section of 1871 invites Democrats of all countries to assist at a

COMMEMORATIVE MEEETING, WHICH WILL BE HELD ON

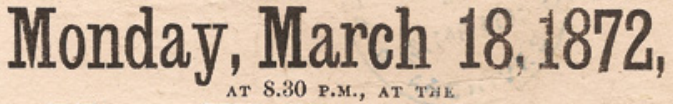
New Hall of Science, CLUB AND INSTITUTE, 142, OLD STREET, CITY RD. THE CHAIR WILL BE TAKEN BY

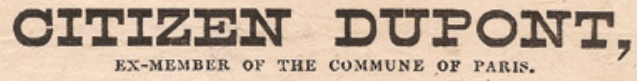

EX-MEMBER OF THE COMMUNE OF PARIS.

Speeches delivered in French will be translated into English. ADIMISSION TWOPENCE.

$$
\text { Orators : }
$$

LANDECK, Delegate from the Commune of Marseilles. LEVERDAYS.

COMBATZ, Chef de Legion. VESINIER, Member of the Commune.

\section{Stembers of the Comminsion:}

A. DUPONT.

B. LANDECK.

LAROQ Central Committec.

E. E. METARD. DEBORD.

FIGURE 7.1 Poster for a commemorative meeting for the anniversary of the Paris Commune, London, 1872. The chairmanship of Eugène Dupont can be explained by his long-term involvement in the IWMA. After taking part in the Franco-British meeting of workers in 1862, Dupont had been a member of the association and of the General Council since 1864. PRIVATE COLLECTION. 


\section{REPUBLIOUE FRANÇAISE}

Liberté. - Égalité. - Fraternité

\section{Association Internationale}

DES TRAVAILLEURS

CONSEIL FEDERAL DES SECTIOHS - PARISIEHIES

Chanibre Fédérale des Sociétés ouvrières

TRAVAILETRS,

Une longue suite de revers, une catastrophe qui sembie devoir eatrainer is raine complite de aotre pays, tel eat le Bllan de Ittaation créte a la France par les gourernements quil Pont dominte.

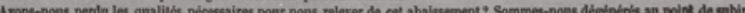

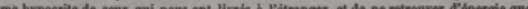
notre rvine irrtmelliable par la greerre civile?

Les derniers ixinements ont dímontré la florce du peuple de Paris, nous sommes conraincus qu'une enteate fraternelle Lenters

Le principe d'antoritế est désormais impuissant pour rétablir l'ordredans la rue, pour faire nenaltre le travail dans rate-

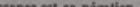

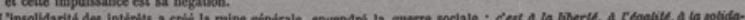

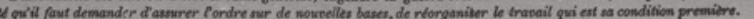
TRAVAILEURS,

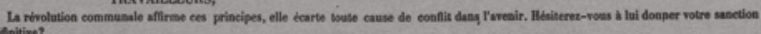

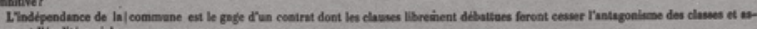

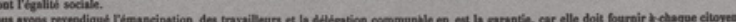

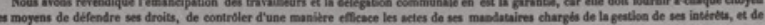

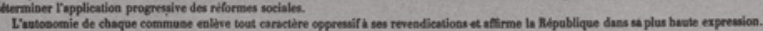

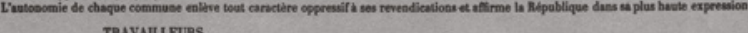
TRAVAILLEURS,

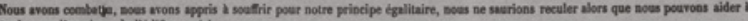

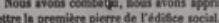

Qu'aroos-aous deemande?

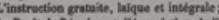

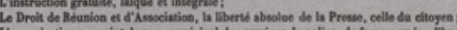

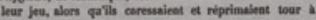

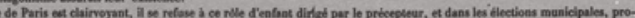

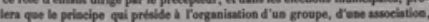

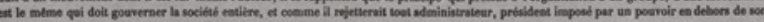

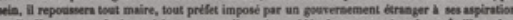

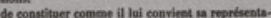

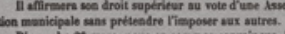

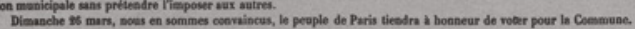

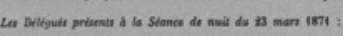

\begin{tabular}{|c|c|c|c|}
\hline \multicolumn{2}{|c|}{ 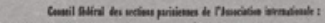 } & \multicolumn{2}{|c|}{ 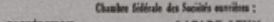 } \\
\hline 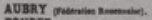 & Lto FRAKKEL. & camtumat & LAZARE LEVY \\
\hline UDER & H. couLte & DEscamps & PIEDY \\
\hline AUDESAlGUES & LAUREAU & $\begin{array}{l}\text { EVETIE } \\
\text { GALARD }\end{array}$ & EERE POITIIR \\
\hline $\begin{array}{l}\text { CoIrEt } \\
\text { v. DEMAY }\end{array}$ & LMoousin & MAAN & ROUVEYROLLE \\
\hline v. DEMAY & MARTIK LĖOK & KAMTI & \\
\hline A. puchitas & Mostag & ARECE & A. THEISZ \\
\hline & C.. ROCHAT & 2. LALLEMAKD & venY \\
\hline
\end{tabular}

FIGURE 7.2 Call of the federal council of the Parisian branches of the IWMA to the workers of Paris for the 26 March 1871 election of the Paris Commune.

(APPEL DU CONSEIL FÉDÉRAL DES SECTIONS PARISIENNES DE L'AIT AUX TRAVAILLEURS DE PARIS POUR LES ÉLECTIONS DU 26 MARS 1871). 


\section{DEMOCRATICASSOCIATION Liberty, Equality, Fraternity. REPUBIICAN DEMONSTRATION} WILC BE RELD DS

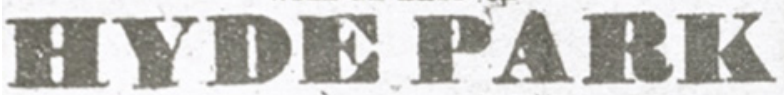
SUINDAY:

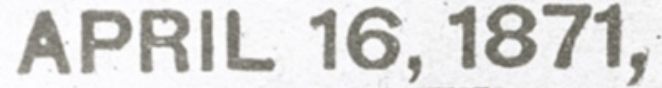

- IN HONOR OF. THB.

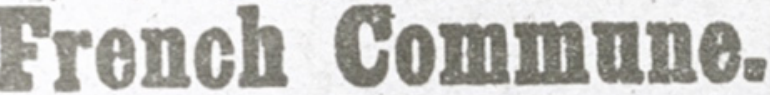

Chair to be taken at $40^{\circ}$ clock. WORKMEN, sttend in your thousands and show your sympathy with your Frenoh Brethren, who are now struggling to emancipate Labour and to found 2

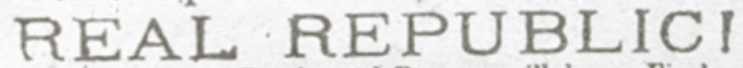

A Procession with Bands and Banners will leave Finsbury Square at half-past 2 o'clock, via Old Street, Clerkenwelf

-Green, Fleet Street, Pall Mall and Piccadilly.

A PRELIMNARY MESTING will bo beld on Clorkenvioll Groen on Sunday Morning, April 9th, at 11 o'olock. Iong Live the Universal Republic, Social \& Democratio! B) Order of the Ooweil $\left\{\begin{array}{l}\text { 9. OLIVER } \\ \text { GUY HLYLER }\end{array}\right\}$ Eob. Bew.

FIGURE 7.3 International democratic association call for a demonstration in Hyde Park, in London, on 16 April 1871 in honour of the French Commune.

COLLECTIONS OF THE UNIVERSITY OF WARWICK. 